Volume 1, Number 2, July 2019

\title{
Review article \\ Work ability of health care professional: Enhancing Productivity
}

\section{Shila Rani Das}

\section{Introduction:}

The work ability can be conceptualized as the physical and mental well-being of workers, which enables them to develop their work according to the demands of the occupation and their state of health ${ }^{1}$. Work ability comprises physical, psychological, and social capacities. It is influenced by demographic, socio-economic, environmental and life style factors. ${ }^{2}$ work ability should be seen from a framework that takes into account the interaction between work, lifestyle, health conditions and biological aging ${ }^{3}$. Work ability can be considered as an important component of the broader concept of employability. It also can be a sign of person's ability to cope with working life. The concept of work ability is defined as the ability of a worker to perform his/her job, taking into account the specific work demands, individual health condition, mental resources and work life ${ }^{4}$.

The correct appraisal of the employees' work ability is important for employers in economic viewpoint and improving it is one of the ways for increasing the human resources productivity in industries and organization. The concept of work ability is the base for designing work stations and proper choose of staffs for various jobs in the other hand, if employee's physical and psychological abilities is not according to their job's requirements, it would led to detect safety and health issues, decreasing production and increasing costs related to dismissal of employees. Quality of healthcare depends on many factors, including health, quality of life and work ability of healthcare workers. Globally, nurses are the largest category of health care workers in the world and provide up to $80 \%$ of direct patient care ${ }^{5}$. Work places with high physical demands, psychological and physical workrelated factors are the most important determinants of work ability. Among physical factors repetitive movements, static work postures, awkward back postures were the most important factors and among psychological factors, lack of support at work, high work demands and low job control and prominent effects on work ability ${ }^{6}$. There is a need for employees to remain productive until retirement age. This need is particularly apparent in health care, due to a shortage of nurses and a high turnover of nursing personnel ${ }^{7}$. Decreased work ability is associated with diminished productivity at work, increased risk of long- term sickness absence and early retirement. Particularly in healthcare jobs, work ability is a precondition to cope with demanding tasks in different work conditions (eg, high patient loads, working under pressure) ${ }^{8}$.

In the 1980s, with the aging of the Finnish working population, the Finnish Institute of Occupational Health (FIOH) began the first studies on work ability and functional aging, based on the stress-wear model of Rutenfraz and Colquhoun. This model assumes that the wear experienced by the worker is dependent on stressors resulting from the physical and mental loads of the work, the labor environment and equipment, and the characteristics and resources of the worker. This wear can lead to the triggering of physiological, psychological and behavioral responses, with an impact on the health of the individual and on his or her work ability ${ }^{9}$.

More specifically, it is the worker's perception of own work ability. Thus, work ability should be measured using multiple criteria. The Finnish Institute of Occupational Health developed one of the most appropriate instruments for measuring work ability during 1980: Work Ability Index (WAI) an instrument translated for 26 languages. "reveals how well a worker is able to perform his or her work". It "is primarily a question of a balance between work and personal resources. In practice people search for an optimal balance throughout their entire work life" and it "may be very different in different phases of work life" The WAI has seven items: (1) current work ability compared with the life time best, (2) work ability in relation to the demands of the job, (3) number of current diseases diagnosed by a physician, (4) estimated work impairment due to diseases, (5) sick leave during the past year, (6) own prognosis of work ability two years from now, (7) mental resources and vary from 7 to 49 points ${ }^{10,11}$. In the context of the world of work, the nursing team corresponds to a portion of the contingent of health workers which routinely perform functions that require physical and psychosocial efforts in unhealthy environments, shift schedules, continuous and direct assistance to patients and relatives, and direct experience of pain, suffering and death. These factors, associated with the complexity of the tasks and, often, with other jobs, can generate, over time, wear of the worker's vital capacities, with consequences for the development of

\section{Address of correspondence:}

Shila Rani Das, Associate Professor, Department of Community Medicine, Z H Sikder Woman's Medical College, Dhaka, Bangladesh. Email:dr.shila@yahoo.com 


\section{Volume 1, Number 2, July 2019}

occupational tasks ${ }^{12,13}$.

Investigating the nursing team's work capacity can contribute to the early identification of the loss of work ability and associated factors and, consequently, to provide for the planning of strategies for health promotion and prevention of injuries, the health maintenance of workers, and possible improvements in the organization and work environment ${ }^{14}$. Nurses are among the many healthcare professionals affected by the requirement to work outside of normal daytime hours, as in working alternate shifts ${ }^{15}$. Nurses are among the many healthcare professionals affected by the requirement to work outside of normal daytime hours, as in working alternate shifts. This may lead to long working hours (12 vs. 8 hours) and nonergonomic planning of work schedules (e.g. lack of rest time between shifts and working consecutive night shifts or weekends.). Hence, difficulties in shift-work-related problems, both for the nurses and for those supervising them, may increase the current global nursing shortage ${ }^{16}$.

It has been agreed that, in the caring profession, nurses form the largest group, of which the principal mission is the nurturing of, and caring for people in the human health experience. They provide around-the-clock services to patients in hospitals, nursing homes, longterm care facilities, as well as to clients using supportive and preventative programs and related community services. The nursing profession follows a holistic approach, taking into account the person in totality in his or her environment. Nurses provide presence, comfort, help and support for people confronted with loneliness, pain, incapacity, disease and even death ${ }^{17}$.

Shift work is a known cause of disturbances in the health and well-being of nurses ${ }^{18}$. However, nursing services must be available on a 24-hour basis, making shift work a necessity. The effect of shift work on nurses' lifestyle, their occupational health issues, and the demands of staffing are documented ${ }^{19}$. Also, adverse effects have been noted on workers' physiological, psychological, and health related problems due to an impairment of biorhythms, although adverse effects vary according to type of shift worked, as in rotational versus fixed shifts ${ }^{20}$.

Factors related to the management, ergonomics, and lifestyles explained both a decline and an improvement in work ability during ageing. In some studies, poor work ability has been associated with older age, obesity, high mental work demands, lack of autonomy, poor physical work environment, and high physical work load. Individuals with poor work ability have an increased risk of early retirement, long-term sickness absence and work disability as well as decreased functional ability and higher mortality in old age ${ }^{21}$.
Large-scale epidemiological studies which aim to describe nurses' quality of life and its main determinants and to assess its associations with work ability and different health outcomes are needed to translate the research findings into evidence based strategies effectively with the final goal being to maintain work ability among nurses ${ }^{22}$. Nowadays, one of the most important personnel management challenges is to explore factors that stimulate or hinder the development of individual work ability and quality of life throughout a career. Maintaining clinical nurses' quality of life and work ability is an important issue, because it is the foundation for the well-being of the workforce ${ }^{23}$. Furthermore, knowledge on the role of basis modifiable lifestyle related and work-related factors is essential for designing effective interventions to improve the workability of workers with health problems and to prevent long-term sickness absence.

\section{References:}

1. Hilleshein EF, Lautert L.Work capacity of nurses in a university hospital. Rev. Latino-Am. Enfermagem. 2012;20(3):[8 telas]. Available at: http://www.scielo.br/pdf/rlae/v20n3/pt a13v20n3.pdf

2. Kordi, M. Mohamadirizi, S. Shakeri, M.T. Gharavi, M.M. \& Fadardi, JS. Relationsehip between Occupational Stress and Work Ability of Midwives in Mashhad. Journal of Midwifery and Reproductive Health. 2011; vol2(3):188-94.

3. Martinez MC, Latorre MRDO, Fischer FM. Capacidade para o trabalho: revisão de literatura. Cienc.saúde coletiva. 2010;15 (supl 1): 1553-61.Available at:http://www.scielo.br/scielo. php?script $=$ sci arttext\&pid $=$ S1413-81232010000700067

4. Ilmarinen J \& Rantanen J (1999) Promotion of work ability during ageing. American Journal of Industrial Medicine 1(Suppl), 21-23

5. World Health Organization. 'Occupational stress in the care of the critically ill, the dying and the bereaved', Hemisphere Publishing Coporation, 2014. Available at: http://whqlibdoc. who.int/publications/2002/924156 217X.pdf

6. Alavinia SM, Duivenbooden C, and Burdorf A. Influence of work-related factors and individual characteristics on work ability among Duch construction workers. Scand J Work Environ Health. 2007; vol 33(5):351-7.

7. Hayes L,j, O’Brien-paalas L, Duffield C, Shamian J, Buchan J, Hughes F et al, Nurse turnover: a literature review. Int J Nurs Stud. 2006;43(2):237-263

8. van den Berg TI, Elders LA, de Zwart BC, et al. The effects of work-related and individual factors on the Work Ability Index: a systematic review. Occup Environ Med 2009;66:21120. doi:10.1136/oem.2008.039883

9. Camerino D, Conway PM, Sartori S, et al. Fac- 
Volume 1, Number 2, July 2019

tors affecting work ability in day and shift-working nurses. Chronobiol Int.2008;25(2): 425-42. Available at: [http://dx.doi.org/10.1080/07420520802118236] [PMID: 18484372]

10. West S, Boughton M, Byrnes M. Juggling multiple temporalities: the shift work story of midlife nurses. J Nurs Manag. 2009; 17(1): 110-9. Available at: [http://dx.doi.org/10.1111/j.13652834.2008.00920.x] [PMID: 19166529]

11. Saberi HR, Moravveji AR. Gastrointestinal complaints in shift-working and day-working nurses in Iran. J Circadian Rhythms. 2010; 8: 9-12. Available at: [http://dx.doi.org/10.1186/1740-3391-8-9] [PMID: 20929565

12. Queiroz DL, Souza JC. Qualidade de vida e capacidade para o trabalho de profissionais de enfermagem. Psicólogo Informação ;16(16):103-26. Available at:https:/www.metodista. $\mathrm{br} / \mathrm{revistas} / \mathrm{revistas}-\mathrm{ims} /$ index.php/PINFOR/article/viewFile/3999/3478

13. Oliveira JDS, Pessoa Júnior JM, Miranda FAN, Cavalcante ES, Almeida MG. Stress of nurses in emergency care: a social representations study. Online braz j nurs . 2014 Jun;13(2):1507. Available at: http://www. objnursing.uff.br/index.php/nursing/article/view/4342 doi: http://dx.doi.org/10.5935/16764285.20144342

14. Cossi MS, Costa RRO, Medeiros SM, Menezes RMP. A capacidade para o trabalho da equipe de enfermagem inserida no ambiente hospitalar. Rev. de Atenção à Saúde, 2015(43):5-9. Available at: http://seer.uscs.edu.br/index.php/revista_ciencias_saude/article/view/2676/pdf_1 doi: 10.13037/rbcs. vol13n43.2374

15. Blachowicz E, Letizia M. The challenges of shift work. Medsurg Nurs 2006; 15(5): 274-80.[PMID: 17128897$]$

16. Camerino D, Conway PM, Sartori S, et al. Factors affecting work ability in day and shift-working nurses. Chronobiol Int. 2008; 25(2): 425-42. Available at:[http://dx.doi. org/10.1080/07420520802118236] [PMID: 18484372]

17. A, H Shivaprasad, RN, and PGCDE. Work related stress of nursing. Journal of Psychiatry Nursing. 2013; 2 (2): 53-59.

18. Martinez MC, Latorre MRDO, Fischer FM. Capacidade para o trabalho: revisão de literatura. Cienc.saúde coletiva . 2010;15 (supl 1): 1553-61.Available at: http://www.scielo.br/scielo. php?script $=$ sci arttext\&pid $=$ S1413-81232010000700067

19. Tuomi K, Toikkanen J, Eskelinen L, Backman AL, Ilmarinen J, Jarvinen E \& Klockars M (1991) Mortality, disability and changes in occupation among aging municipal employees. Scandinavian Journal of Work and Environmental Health 17(Suppl 1), 58-66.
20. J. Ilmarinen, Work ability - a comprehensive concept for occupational health research and prevention, Scand. J. Work Environn. Health, 2009, 35, 1-5. [7] K.

21. von Bonsdorff $\mathrm{MB}$, Seitsamo J, Ilmarinen J, Nygård CH, von Bonsdorff ME, Rantanen T. Work ability in midlife as a predictor of mortality and disability in later life: a 28-year prospective follow-up study. CMAJ. 2011 Mar;183(4):E235-42. http://dx.doi.org/10.1503/ cmaj.100713.

22. Peterson, M. \& Wilson, J. F. The culture-work-health model and work stress. American Journal of Health Behavior. 2002. Vol 26(1): 16-24.

23. Milutinovic, D. Golubovic, B. Brkic, N. and Prokes, B. Professional stress and health among critical care nurses in Serbia. Arh hig Rada Toksikol. 2012; vol 63(1)

\section{Journal of ZHSWMC}

